\title{
Compliance with pharmacological treatment in outpatients from a Brazilian cardiology referral center
}

\author{
Instituto do Coração, Hospital das Clínicas, University of São Paulo - São Paulo, Brazil
}

\begin{abstract}
To evaluate the degree of compliance with pharmacological therapy, and to identify predictors of non-compliance in outpatients from a cardiology referral center in São Paulo, Brazil, we studied 485 outpatients, 230 (47.4 percent) males and 255 ( 52.6 percent) females, through an interview guided by a questionnaire during medical consultation. The ages ranged between 17 and 86 (mean 54 , standard deviation 15) years. Heart disease and socioeconomic factors (residence, means of transport, educational level and professional status) were studied. In addition, we examined the drugs prescribed including: difficulties in taking them; the source of supply; and the patient's knowledge of the drugs. Assessment of compliance was based on the patients' response. The patients' answers were compared with the prescription and progress notes. Errors were recorded if the patient reported using one or more nonprescribed medicines. Compliance with therapy was recorded if the patient said the prescription was taken correctly without interruption and without error. The variables with significant differences in univariate analysis were further analyzed by multivariate log-linear regression analysis. Noncompliance occurred in 286 (59 percent) of the patients, and was predicted by the reported difficulty in taking medication $(P<0.001)$, and by the lack of knowledge of medication names $(P<0.001)$. Thus, noncompliance with medical therapy was common. The main predictors of non-compliance were the reported difficulty in taking medication and inability to identify medicines' names.
\end{abstract}

UNITERMS: Patient compliance. Ambulatory care. Outpatient clinics.

\section{INTRODUCTION}

$\mathrm{C}$ ompliance of patients with the therapeutic regimen is a fundamental step in medical care, affecting the evaluation of either treatment or disease..$^{1.4}$ Treatment compliance depends on the complex interaction of several variables including: the patient; ${ }^{5-9}$ the physician,,$^{5.6 .89}$ the disease $;^{5-9}$ and the drug, ${ }^{6-9}$ among other factors. $^{5-9}$ The interaction of these variables is operative in the cultural and socioeconomic environment in which the patients are living. Different degrees of compliance are to be expected in different populations. Patients should be considered potential defaulters and compliance should not be assumed. ${ }^{10}$

In order to assess the compliance with pharmacologic medical treatment by the patients we care for, we studied the compliance with medical treatment in an outpatient setting located at a tertiary cardiology referral center in São Paulo, Brazil.

\section{METHODS}

Patients - in the study period of seven months, 18,722 medical consultations were performed in one

\author{
Adress for correspondence: \\ Paulo Roberto Chizzola \\ Instituto do Coração HC-FMUSP. Divisão de Clínicas \\ Av. Dr. Enéas de Carvalho Aguiar, 44 \\ São Paulo/SP - Brasil - CEP 05403-000
}


outpatient section of the center; 5,822 (31.1 percent) of them were unscheduled visits. Among these, 485 (8.3 percent) were interviewed by two physicians guided by a questionnaire (given during the medical consultation). Two hundred fifty-five ( 52.6 percent) patients were female and 230 (47.4 percent) were male. The ages ranged between 17 and $86(54 \pm 15)$ years. Duration of follow-up ranged from one day to $14.2(3.6 \pm 3.1)$ years. The patient was interviewed during the consultation, and the comparison of the answers with the last prescription was noted. Progress notes in the charts were made.

Outpatient clinics - our referral center is a public hospital with a large outpatient facility for cardiological care. A section of our outpatient clinics provides medical care for patients with state health insurance for their first medical visit to the hospital, as well as for outpatients who have been on treatment in the hospital and come for unscheduled medical visits. The saturation of the appointment system diverts patients, who come to the hospital for appointments, to unscheduled medical visits. Thus, unscheduled medical visits represent patients that came to the hospital for medical reasons as well as patients who were not scheduled in the appointment system, and come to the hospital for different reasons.

Variables - Age; sex; duration of follow-up; residence; means of transport to the hospital; educational level; professional status; reason for unscheduled medical visit; main cardiac disease and functional class (New York Heart Association);" duration of medicine use; number of drugs prescribed and the daily regimen; help from others in taking medicines; knowledge of the name of at least half of medicines in use, or at least to designate half of them; free acquisition of the drug or not; reported difficulty

\section{Table 1}

Frequency of main difficulties in taking medications

\begin{tabular}{lrr}
\hline Reported Difficulties & $\mathrm{n}$ & $\%$ \\
\hline Side effects of drugs & 45 & 27.6 \\
Cost of drugs & 41 & 25.2 \\
Negligence & 26 & 15.9 \\
Repulse to medications & 25 & 15.3 \\
Attenuation of symptoms & 12 & 7.4 \\
Absence of the drug & & \\
on the market & 6 & 3.7 \\
Other reasons & 8 & 4.9 \\
Total & 163 & 100 \\
\hline
\end{tabular}

n: number

$\%$ : percentage in taking medical prescription or not; interruption in taking the drugs; and self-assessment by the patient of their own compliance.

Definitions - Error was recorded if the patient reported using one or more medicines differently than prescribed.

Compliance was recorded if the patient said he took the prescription correctly, without interruption in medicine use (reported data), and without error (observed data).

Noncompliance was recorded if the patient said he took the prescription incorrectly, or with interruption in medicine use (reported datas), or with error (observed data).

Statistical Analysis - Chi-square test was used for univariate frequencies of categoric variables and the Students $t$ test for the continuous variables. The variables with a significant differences in univariate analysis $(\mathrm{P} \leq 0.25)$ were subsequently analyzed by multivariate $\log -$ linear regression analysis. ${ }^{12.13} \mathrm{~A}$ significance level of 0.05 was adopted.

Demographic and Clinical Characteristics Residence - 321 (66.2 percent) patients lived in São Paulo City, 79 (16.3 percent) in the metropolitan area, 55 (11.3 percent) in the interior of São Paulo state, and 30 (6.2 percent) in other states.

Transport - Bus, train or subway (public transport) were used as transport for the visit by 351 (72.4 percent) patients, and private car, taxi, ambulance and other (individual transport) by 134 (27.6 percent).

Educational level - 92 (19 percent) patients were illiterate; 309 (63.7 percent) had a elementary school education ( 1 to 4 school years), and 84 (17.3 percent) had more than 4 school years.

Professional status - 164 (33.8 percent) patients were employed, and 321 (66.2 percent) were unemployed, retired or dependent.

Heart disease - Clinical problems were the reason for unscheduled visits in 220 patients (45.4 percent). Among these, 123 (55.9 percent) were due to cardiovascular complications, and 97 (44.1 percent) due other clinical reasons. Causes unrelated to clinical problems led to unscheduled visits in 265 ( 54.6 percent) patients. The diagnoses were: coronary artery disease in 145 (29.9 percent) patients; arterial hypertension in 112 (23.1 percent); valvular heart disease in 110 (22.7 percent); cardiomyopathy in 73 (15.1 percent); and other cardiac diseases in 45 ( 9.3 percent). The functional class was II in 235 (48.5 percent) patients, I in 217 (44.7 percent) and III or IV in 33 (6.8 percent).

Treatment - 342 (70.5 percent) patients were able to identify at least half of medicines and 121 ( 24.9 percent) 
Table 2

Frequency of prescribed drugs

\begin{tabular}{lrr}
\hline Pharmacological group & $\mathrm{n}$ & $\%$ \\
\hline Diuretic & 356 & 25.9 \\
Noncardiologic drugs & 184 & 13.4 \\
Digitalic & 164 & 11.9 \\
Platelet atiagregant & 125 & 9.1 \\
Calcium chanel blockers & 96 & 7.0 \\
Beta blockers & 90 & 6.6 \\
Other antihypertensive drugs & 74 & 5.4 \\
Nitrates & 73 & 5.3 \\
Potassium replacement & 58 & 4.2 \\
Inhibitors of ACE & 57 & 4.2 \\
Other antiarrhytmic agents & 45 & 3.3 \\
Benzathine penicillin & 34 & 2.5 \\
Oral anticoagulant & 17 & 1.2 \\
Total & 1,373 & 100.0 \\
\hline
\end{tabular}

$\mathrm{n}$ : frequency of drugs

$\%$ : percentage

ACE: angiotensin-converting enzyme

were not. Someone's assistance in taking medicine occurred in 121 (24.9 percent) patients. Two hundred thirty-six (48.7 percent) patients were on drugs for more than five years, 189 (37.9 percent) for one to five years, and 65 (13.4 percent) for less than one year. Medicines were given free especially in 318 (65.6 percent) patients, and in 167 (34.4 percent), the medicine was more frequently purchased. Difficulty in caring out medical prescriptions was denied in 322 (66.4 percent) patients. The main causes of reported difficulty are in Table 1.

Drugs - The number of the medicines for each prescription ranged from 1 to $8(2.8 \pm 1.5)$. The classes of drugs prescribed are in Table II. The prescribed regimens were to be taken once a day for 729 (53.1 percent) drugs, twice a day for 319 (23.2 percent), three or more times a day for 163 (11.9 percent), and other regimens for 110 (8.0 percent), and in 52 (3.8 percent) it was unknown.

\section{RESULTS}

Noncompliance occurred in 286 patients ( 59 percent) and compliance in 199 (41 percent) - (Table 3). Among the noncompliant patients, 196 (68.5 percent) took medicines with error and the range of error of each medical prescription ranged from 12.5 to 100 percent (mean 54.7 percent, standard deviation 28.3 percent).

After log-linear regression analysis, the variables which exerted significant influence on the compliance

$\log (p / 1-p)=1.0622+0.4160$ NAM - 1.1307DIF, where p: expected probability NAM: medicines' name; $+1=$ ignored $-1=$ known

DIF: difficulty; $+1=$ without difficulty, $-1=$ with difficulty

were: the reported difficulty in taking prescribed medicines $(\mathrm{P}<0.001)$, and the knowledge of the name at least half of the medicines in use $(\mathrm{P}<0.001)$. The interaction of these two variables was not significant.

The reported difficulty in taking the medical prescription was more frequent in the noncompliant group than in the compliant group. There was a higher frequency of patients who knew the name of at least half of medicines in use in the compliant group, compared to the noncompliance group (Table 3 ).

The chance of noncompliance is 93.1 percent when the patient ignores the name of at least half of medicines in use and reports difficulty in taking medical prescriptions. In contrast, the probability is 38.1 percent when the patient knows the name of medicines and does not report difficulty.

The others variables: age; sex, duration of follow up, residence; means of transport to come to the hospital; educational level; professional status; reason for unscheduled medical visit; main cardiac disease; the functional class; duration of medicine use; number of drugs prescribed; assistance from others in taking medicines; and free acquisition of the drug did not exert influence on the compliance (Table 3 ).

\section{DISCUSSION}

The method we used for assessing compliance was chosen for its low cost and feasibility in routine clinical practice. ${ }^{5.1 .14}$ Usually, the patients are less compliant than suggested by the interview. ${ }^{8.14}$ This method is able to identify 25 to 50 percent of noncompliant patients, and compliance may be overestimated. ${ }^{1.14}$ Noncompliance was identified in 59 percent of our patients; a finding that may be an underestimation. Local characteristics of the health care 
Table 3

Frequency of variables relative to compliance and noncompliance

\begin{tabular}{|c|c|c|c|c|c|c|}
\hline \multirow[t]{2}{*}{ Variables } & & \multicolumn{2}{|c|}{ Compliance } & \multicolumn{2}{|c|}{ Noncompliance } & \multirow[t]{2}{*}{$\mathbf{P}$} \\
\hline & & mean & sd & mean & sd & \\
\hline Age & (years) & 53.4 & 15.1 & 54.4 & 14.0 & 0.42 \\
\hline \multirow[t]{2}{*}{ Follow up } & (years) & 3.4 & 2.9 & 3.8 & 3.2 & 0.18 \\
\hline & & $\mathrm{n}$ & $(\%)$ & $\mathrm{n}$ & $(\%)$ & \\
\hline $\begin{array}{l}\text { Total of } \\
\text { Patients }\end{array}$ & & 199 & 41.0 & 286 & 59.0 & \\
\hline \multirow[t]{2}{*}{ Sex } & male & 93 & 46.7 & 137 & 47.9 & 0.8 \\
\hline & female & 106 & 53.3 & 149 & 52.1 & \\
\hline \multirow[t]{2}{*}{ Residence } & São Paulo & 127 & 63.8 & 194 & 67.8 & 0.381 \\
\hline & other & 72 & 36.2 & 92 & 32.2 & \\
\hline Means of & private & 65 & 32.7 & 75 & 26.2 & 0.19 \\
\hline Transport & public & 134 & 67.3 & 211 & 73.8 & \\
\hline \multirow[t]{2}{*}{ Instruction } & illiterate & 30 & 15.1 & 63 & 22.0 & 0.157 \\
\hline & 1 to 4 years & 134 & 67.3 & 175 & 61.2 & \\
\hline Professional & employed & 67 & 33.7 & 97 & 33.9 & 0.298 \\
\hline Status & retired/unemployed & d 61 & 30.7 & 104 & 36.4 & \\
\hline \multirow{2}{*}{$\begin{array}{l}\text { Reason for } \\
\text { Visit }\end{array}$} & clinical & 94 & 47.2 & 126 & 44.1 & 0.489 \\
\hline & nonclinical & 105 & 52.8 & 160 & 55.9 & \\
\hline \multirow[t]{5}{*}{ Heart disease } & hipertension & 39 & 19.6 & 73 & 25.5 & 0.44 \\
\hline & coronary disease & 64 & 32.2 & 81 & 28.3 & \\
\hline & valvular disease & 48 & 24.1 & 62 & 21.7 & \\
\hline & cardiomyopathies & 27 & 13.6 & 46 & 16.1 & \\
\hline & others & 21 & 10.6 & 24 & 8.4 & \\
\hline \multirow{3}{*}{$\begin{array}{l}\text { Functional } \\
\text { Class }\end{array}$} & 1 & 94 & 47.2 & 123 & 43.0 & 0.053 \\
\hline & II & 98 & 49.2 & 137 & 47.9 & \\
\hline & IIIVIV & 7 & 3.6 & 26 & 9.1 & \\
\hline \multirow[t]{2}{*}{ Time on drug } & $<5$ years & 99 & 49.7 & 150 & 52.4 & 0.596 \\
\hline & $>5$ years & 100 & 50.3 & 136 & 47.6 & \\
\hline \multirow{2}{*}{$\begin{array}{l}\text { Number of } \\
\text { drugs }\end{array}$} & one to four & 180 & 90.5 & 245 & 85.7 & 0.115 \\
\hline & five or more & 19 & 9.5 & 41 & 14.3 & \\
\hline \multirow{4}{*}{$\begin{array}{l}\text { Assistance } \\
\text { in taking } \\
\text { Medicine's } \\
\text { name }\end{array}$} & yes & 42 & 21.1 & 79 & 27.6 & 0.103 \\
\hline & no & 157 & 78.9 & 207 & 72.4 & \\
\hline & is known & 157 & 78.9 & 185 & 64.7 & 0.001 \\
\hline & is not known & 42 & 21.1 & 101 & 35.3 & \\
\hline \multirow[t]{2}{*}{ Acquisition } & free & 121 & 60.8 & 197 & 68.9 & 0.066 \\
\hline & purchased & 78 & 39.2 & 89 & 31.1 & \\
\hline \multirow[t]{3}{*}{ Difficulty } & yes & 19 & 9.5 & 136 & 47.6 & $<0.001$ \\
\hline & no & 180 & 90.5 & 142 & 49.7 & \\
\hline & no information & - & - & 8 & 2.7 & \\
\hline
\end{tabular}

sd: standard deviation; n: number of patients; \%: percentage

delivery system in the hospital, includes saturation of the appointment system, which diverts patients with a variety of medical and nonmedical conditions to unscheduled visits. In this context, we should not assume that unschedule visits were associated with noncompliance in our study. In fact,
94 percent of the studied population was in a similar functional class (I/ II), as was the outpatient population, and there was no significant difference between frequency of clinical and nonclinical reasons for unscheduled visits, and only half the of clinical reasons were cardiovascular complications. Thus, our results might be useful for planning educational strategies for enhanced compliance in outpatient clinics.

The reported difficulty in taking medicines exerted influence on the compliance. The main reported difficulty was side effects of the drugs (Table 1). Noncompliance is expected if adverse effects are identified. ${ }^{5-7.15}$ However, in other study, one-third of patients who complained of an adverse symptom seldom had their therapeutic regimens modified. ${ }^{15}$ The cost of drugs is also involved in noncompliance. ${ }^{5-7.16}$ The cost of prescriptions in the noncompliant group is three times higher than in the compliant group. Usually, patients with cardiac disease have the most expensive prescriptions. ${ }^{7}$ In Brazil, the annual medicine comsumption per capita is US\$13, and about 52 percent of population was considered to be out of the market. ${ }^{17}$ Acquisition of drugs was free to 65.6 percent of our patients. Even so, in our observation, the free drug dispensation did not influence compliance. 
Patients who were not able to name at least half the drugs were more frequently associated with noncompliance. To encourage compliance, an educational program should cover drug dispensation. ${ }^{7.14}$ In this context, in Nigerian patients under treatment for arterial hypertension, the economic factor was not the major limitation to the control of blood pressure after the educational program. ${ }^{18}$ Nurses visits before or after medical consultation also enhanced compliance. ${ }^{4}$ When patients understood the purpose of the treatment and knew the names of their medications, complianced was also optimized. ${ }^{19}$ Another recommendation to enhance compliance is to increase the patient participation in medical decisions. ${ }^{20}$

In our study, the age, means of transport, educational level, professional status, cardiac disease, functional class, and number of drugs prescribed did not influence the compliance. There is no agreement on the relationship between socioeconomic and educational level in compliance. ${ }^{5.7 .21}$ Severity of disease was not related to compliance $^{22}$ and, according to other studies, the frequency of error increased with the number of drugs precribed. $^{5-7,21.22}$

In addition to reported difficulty in taking medication, the single variable having significant influence on compliance was the knowledge of the name of the drug. Efforts in identifying noncompliant patients should include these specifics questions.

In conclusion, noncompliance with medical therapy was common in this studied population, in spite of free drug dispensation. Reported difficulty in taking prescribed medicines, as well as the inability to identify the names of the medicines by the patient, were the clues to revealing noncompliance. These data may be useful for comprehensive intervention aimed at improving the approach to compliance and therapeutic success.

\section{RESUMO}

Com o objetivo de avaliar a aderência ao tratamento medicamentoso em hospital voltado para 0 atendimento cardiológico. foram estudados 485 doentes, $230(47.4 \%)$ homens e $255(52.6 \%)$ mulheres. As idades variaram de 17 a $86(54+15)$ anos. Foram analisados a cardiopatia, fatores socioeconômicos (residência, meio de transporte, nivel educacional, condiçāo profissional), drogas prescritas, dificuldade em tomar a medicação, obtenção do medicamento, e conhecimento sobre o medicamento. A aderência se fundamentou na reposta do paciente, que era comparada com a receita e com as notas da evolução clínica. Foi considerado erroquando o paciente usava a medicaçāo de modo diferente do prescrito. Foi considerada aderência quando o paciente informava tomar a medicaçāo corretamento. sem interrupção e sem erro. As variáveis com distribuiçāo diferente na análise univariada foram examinadas com análise multivariada (regressāo log-linear). A falta de aderência ao tratamento ocorreu em $286(59 \%)$ pacientes. Os fatores preditores de nāo aderência foram informação de dificuldade em tomar a medicação $(p<0.001)$ e desconhecimento do nome da medicação $(p<0.001)$. Portanto, a falta de aderència ao tratamento medicamentoso foi frequente. Os principais preditores, informação de dificuldade em tomar a medicação, e desconhecimento do nome da medicação, podem ser obtidos com facilidade na prática médica.

\section{REFERENCES}

1. Roth HP, Caron HS. Accuracy of doctors' estimates and patients' statements on adherence to a drug regimen. Clin Pharmacol Ther 1978; 23:361-70.
2. Feinstein AR. On white-coat effects and the eletronic monitoring of compliance. Arch Intern Med 1990; 150:1377.

3. Horwitz RI, Viscoli CM, Berkman L, et al. Treatment adherence and risk of death after a myocardial infarction. Lancet 1990; 336: 542-545. 
4. Giorgi DMA. Estudo sobre algumas variáveis que influenciam a aderência ao tratamento em hipertensão arterial [Thesis]. Såo Paulo, Brazil: University of São Paulo, 1989. $71 \mathrm{p}$.

5. Blackwell B. The drug defaulter. Clin Pharmacol Ther 1972; 13:841-8.

6. Blackwell B. Patient compliance. N Engl J Med 1973; 289: 249-52.

7. Brand FN, Smith RT, Brand PA. Effect of economic barriers to medical care on patients' noncompliance. Public Health Reports 1977;92:72-8.

8. Evans L, Spelman M. The problem of noncompliance with drug therapy. Drugs 1983;25:63-76.

9. Eraker SA, Kirscht JP, Becker MH. Understanding and improving patient compliance. Ann Intern Med 1984;100: 258-68.

10. Porter AMW. Drug defaulting in a general practice. Br Med J 1969;1:218-22.

11. The Criteria Committee of New York Heart Association, Inc.: Diseases of the Heart and Blood Vassels; Nomenclature and Criteria for Diagnoses 6th ed. Boston: Little, Brown, 1964.

12. SAS Institute Inc; SAS/STATr User's Guide, Version 6, Fourth edition, volume 1, Cary, NC: SAS Institute Inc; 1989: 943.

13. Hosner DW, Lemeshow S. Applied logistic regression. New York: John Wiley \& Sons, 1989.
14. Norell SE. Methods in assessing drug compliance. Acta Med Scand 1983;683:35-40.

15. Klein LE, German PS, Levine DM, Feroli ER, Aldery J. Medication problems among outpatients - a study with emphasis on the elderly. Arch Intern Med 1984;144:1185.

16. Gurwitz JH, Soumerai SB, Avorn J. Improving medication prescribing and utilization in the nursing home. J Am Geriatr Soc 1990; 38:542-52.

17. Castelo A, Colombo AL, Holbrook AM. Production and Marketing of Drugs in Brazil. J Clin Epidemiol 1991; 44(Suppl II):21S-28S.

18. Olubodun JOB, Falase AO, Cole TO. Drug compliance in hypertensive Nigerians with and without heart failure. Int J Cardiol 1990;27:229-34.

19. Stewart RB, Cluff LE. A review of medication errors and compliance in ambulant patients. Clin Pharmacol Ther 1972;13:463.

20. Brody DS. The patient's role in clinical decision making. Ann Intern Med 1980;93:718-22.

21. Hulka BS, Kupper LL, Cassel JC, Efird RL. Medication use and misuse: Physician-patient discrepances. J Chron Dis 1975;28:7-21.

22. Eisen SA, Miller DK, Woodward RS, Spitznagel E, Przybeck TR. The effect of prescribed daily dose frequency on patient medication compliance. Arch Intern Med 1990;150:1881. 